\title{
FINAL SONORANT SEQUENCES IN THE CELJE DIALECT'1
}

\section{Introduction}

In this paper I will analyse final sonorant sequences ${ }^{2}$ in the Celje variety of Slovene. In $\$ 2$ various definitions of a consonant cluster will be discussed and the definition needed for further development of the article will be provided. In §3 I will present pretheoretical arguments against treating all final sonorant sequences as consonant clusters. In addition, a seemingly special behaviour of a small group of sequences will be pointed out. The government phonology framework will be introduced in $\S 4$. In $\S 5$ the data from the Celje dialect will be analysed within the given theoretical framework.

\section{Consonant clusters}

Let us have a look at definitions of the term consonant cluster.

Toporišič $(1959,203)$ claims that consonant clusters are sequences of consonants in words, word units and on word boundaries. They fall into three categories: initial, intervocalic and final clusters. The order of cluster members is not arbitrary; vowels are flanked by sonorants, in front of sonorants and after them appear obstruents. Toporišič observes the "increase" of sonorants when preceding a vowel, which can be interpreted as a sequence of sonorants ordered according to the sonority sequencing principle. The sonority sequencing principle requires the more sonorous segments to appear closer to the vowel (the most sonorous part of the syllable) (Kenstowicz, 1995). The relative sonority of segments is read off the sonority scale (as proposed in Srebot Rejec $(1992,228)$ for sonorants). Although Toporišič (1959) is not specific about the "decrease" of sonorants in positions following a vowel we can assume it exists as a logical opposition to the "increase" in initial positions.

Unuk $(2003,48)$ uses the term consonant sequences instead of consonant clusters to underline the importance of the ordering of consonants. The ordering of members in a sequence is determined by phonotactic principles, the most prominent among them being the sonority sequencing principle, which relies on the sonority scale (1).

(1) stops, fricatives, affricates $<$ nasals $<$ sonorants $<\mathrm{r}<$ vowels (taken from Unuk (2003))

\footnotetext{
${ }^{1}$ I would like to thank dr. Erika Kržišnik for her helpful comments on the draft of this paper. The remaining errors are mine.

2 This paper focuses merely on final sonorant sequences. However, the same analysis I propose for final sequences would also apply to sonorant sequences in preconsonantal position.
} 
In addition, Unuk distinguishes true consonant sequences (consonant clusters in our terminology, see (2)) from bogus sequences. The former belong to the same syllable while the members of the latter belong to different syllables. The distinction is guided by the sonority sequencing principle: the former obey it, the latter do not.

Srebot Rejec $(1992,228)$ similarly observes that any arbitrary sequence of consonants does not necessarily stand for a consonant cluster, since the latter is conditioned by the sonority sequencing principle. She argues that final consonant sequences in butelj [butl] 'an idiot' ${ }^{3}$ and siten [sitn] ]'fussy, masc.' do not represent consonant clusters but sequences of two consonants with the second consonant having the value of a syllable. ${ }^{4}$

Although the definition of a consonant cluster does not seem very unified, a common tendency can be recognized in all the given works. For the purpose of this paper let us assume the following definition of a consonant cluster:

(2) Final consonant clusters are those final consonant sequences that belong to the same syllable as the vowel preceding them.

It will be assumed that consonant clusters are subject to the sonority sequencing principle as in (3).

(3) Sonority must decrease from the vowel to the margins of a syllable. The ranking of consonants according to their sonority is given in a sonority scale.

When not referring to a particular work which uses the term cluster the term sequence will be used from now on in the most general way to avoid any implication as to whether a series of consonants in question are a part of the same syllable as the preceding vowel or not.

\section{Sonorant sequences and syllabic consonants}

\subsection{The sonority sequencing principle in final sonorant sequences}

Srebot Rejec (1992) proposes the following sonority scale for sonorants (4).

(4) $\mathrm{v}<\mathrm{m}, \mathrm{n}<1<\mathrm{r}<\mathrm{j}$

She argues that sonorant clusters in final positions must obey the sonority sequencing principle, which means that they are of falling sonority (as in the word gostiln 'a pub, gen.pl.').

The Celje pronunciation of the word kalen 'muddy, masc.' shows vocalic reduction in the last syllable, thus we get [kaln]. This kind of a final sonorant

\footnotetext{
3 The data are in the nominative singular, unless indicated otherwise.

${ }^{4}$ The phenomenon of sonorants being the most sonorous parts of the syllables is also found in languages such as Slovak, Czech, English, German and others.
} 
sequence obeys the sonority sequencing principle, which suggests that it could belong to the same syllable as the vowel preceding it and could thus be a consonant cluster as defined in (2).

Alongside the falling sonority final sequences the rising sonority final sequences (again as a result of vocalic reduction) can be found in the Celje dialect, as in the word kanilo [kan!'to drip, past part., neuter'. According to (3) a final sequence of / $\mathrm{n} /$ and / $1 /$ can never be a consonant cluster. This is also confirmed by the intuition of the speakers that such a sonorant sequence is a syllable on its own. ${ }^{5}$ However, the same intuition applies for the final sequences in [kaln] and [gostiln], which could, according to (4), represent true consonant clusters but apparently never do. Recall that Srebot Rejec $(1992,228)$ proposes that the second member of the final consonant sequence as in [butl] has a value of a syllable, and is thus called syllabic. Due to the apparent similarity, let us propose the same for the second member of a final sonorant sequence in the Celje dialect.

The Celje dialect permits not only the given pair of sonorant sequences $[\mathrm{nl}] /[\mathrm{ln}]$ but also most other sonorant sequences ${ }^{6}$ regardless of the sonority sequencing principle. In each of the cases the second member of a sequence is always syllabic.

We can conclude this section by claiming that final sonorant sequences in the Celje dialect are not subject to the sonority sequencing principle. The aim of the sonority sequencing principle is to predict distribution of segments within the scope of a syllable. We have seen that in the Celje dialect a final sonorant sequence does not belong to the same syllable as the preceding vowel, ${ }^{7}$ but is a syllable on its own. Therefore any attempt to analyse the given sequences by referring to the sonority sequencing principle would be misleading.

\subsection{Toporišičs's categorisation of words with final sonorant sequences}

Toporišič (1978) observes that words with final sonorant sequences fall into four categories.

The first one is represented by words that insert a schwa between the two sonorants in the nominative singular (jarem 'a yoke').

The second group consists of words in which a schwa immediately precedes the sonorant cluster, therefore the cluster is not broken by an additional schwa (trn 'a thorn', obrv 'an eyebrow'). The same is true for loan words (film 'a film'). However, Toporišič himself observes that words from this group have a tendency to syllabify the sonorant sequence by means of inserting an additional schwa (trn is realised as [tərən]) or by vocalising the final sonorant (obrv is realised as [obəru]).

The third group is represented by words in the genitive plural that tend to be as

\footnotetext{
5 The data concerning the number of syllables in this paper are acquired by using simple experiments on rhythm and verse.

${ }^{6}$ Sequences with $/ \mathrm{r} /$ as the second member are exceptions to this. The reason for the inability of $/ \mathrm{r} /$ to become syllabic lies most likely in its melodic structure. (A discussion on this is beyond the scope of the present paper.) Whenever $/ r$ / is to appear as the second member of a final consonant sequence, a vowel (usually a schwa) is phonetically realised immediately before it.

${ }^{7}$ With the exception of sequences with a glide /j/ as the first member of the sequence (see $\S 3.2$ ).
} 
faithful as possible to the the nominative singular form, therefore they avoid the insertion of a schwa (tovarn 'a factory, gen.pl.', trm 'stubbornness, gen.pl.').

The fourth group consists of words in the genitive plural (morij 'a sea, gen.pl.', slavij 'a celebration, gen.pl.'), which have undergone the "the hardening of $j$ into $-i$, which is then followed by an additional $\mathrm{j}$ due to the analogy with other cases" (Toporišič, 1978, 46).

Let us now go back to the Celje dialect. What we observe is that words that Toporišič painstakingly devides into the first three groups behave exactly the same: the second member of the sonorant sequence becomes syllabic (5).

\section{(5) kalen [kaln], trn [tərn], film [film]}

The only exception we observe here are sequences with $/ \mathrm{j} /$ as the first member, as in fajn 'good, colloquial' and mejl 'e-mail, colloquial', which are according to the speakers' intuition monosyllabic words. Srebot Rejec $(1992,229)$ independently proposes that these sequences are not really clusters since [j] forms a diphthong with a previous vowel. Another explanation might be that these sequences are actually the only final sonorant clusters that can be found in the Celje dialect.

We observe that the behaviour of words that belong to Toporišičs fourth group seems different from other words in the Celje dialect as well. Toporišič's explanation seems to be rather complicated, since it involves two processes: the "hardening" of a segment into another segment and the analogy (the relevant example is morje/morij 'a sea, nom.sg./gen.pl.'). It is disputable whether it is necessary to make use of two unrelated processes that turn one segment into another one and then call back the identity of the first one.

If the behaviour of final sonorant sequences with $/ \mathrm{j} /$ as the last member is truly different from the behaviour of other final sonorant sequences, then a phonological theory that attempts to explain not only describe phonological phenomena should find reasons for this discrepancy. We will come back to this issue once we are armed with a good theory. For the time being let us pretheoretically propose that since other sonorants (except $/ \mathrm{r} /$ ) can become syllabic in the final position of a final sonorant sequence, $/ \mathrm{j} /$ also becomes syllabic.

\section{Theoretical background}

We shall be analysing final sonorant sequences within the government phonology framework (Kaye et al., 1985, 1990), more precisely in the strict CV approach (Lowenstamm, 1996; Scheer, 2004).

In government phonology a phonological string consists of a series of positions. There are two types of positions: $\mathrm{C}$ and $\mathrm{V}$. The former type roughly corresponds to consonants and the latter to vowels. These two types of positions have to alternate in a phonological string. A $\mathrm{C}$ starts a phonological string and a $\mathrm{V}$ finishes it.

A set of items that determine pronunciation and perception is attached to the positions in autosegmental fashion (see Goldsmith, 1976). These items are called elements and represent melodic material attached to a particular position. The 
theory uses only a small number of elements, the most radical versions recognize only six of them (for discussion cf. Neubarth and Rennison, 1998, 2005). The same elements can appear in a $\mathrm{C}$ or a $\mathrm{V}$ position-the nature of the position will determine the exact pronunciation. For instance, the phonetic realization of the element I will be a glide / $\mathrm{j} /$ when attached to a $\mathrm{C}$ position, and a vowel /i/ when attached to a $\mathrm{V}$ position. Adjacent positions can also share melodic material. The melody sharing can either be lexical (already in our mental lexicon) or the result of a phonological process called spreading that allows elements to spread from a position to its adjacent positions of the same or different type.

To use a skeleton of alternating Cs and Vs to represent the structure of words in a language that only permits syllables consisting of one consonant followed by one vowel hardly poses any problems. What about a language with consonant clusters? In such cases the strict $\mathrm{CV}$ approach allows a position to remain inaudible if it is empty, i.e.without melodic material. Also, the distribution of inaudible $\mathrm{V}$ positions is not arbitrary. It is constrained by the empty category principle (ECP), which can be satisfed in different ways. For the purpose of this paper let us discuss only two of them.

Let us take a Slovene word like kanta 'a bin.' Although it lacks an audible vowel between $\mathrm{n}$ and $\mathrm{t} I$ claim that its structure consists of three CV pairs as shown in (6) ${ }^{8}$.

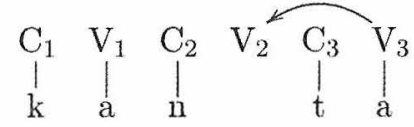

The theory allows positions to become involved in two different types of relations. The relations are strictly local and always involve exactly two adjacent positions, the direction of a relation is from right to left. The source of the relation is a phonetically audible position.

Since position V2 in (6) is inaudible, it has to satisfy the empty category principle. A way of satisfying the ECP is to be the target in the governing relation (or government) with the following $\mathrm{V}$. We can say that position V3 governs position V2 and thus allows it to remain inaudible (the governing relation is marked by a single arrow). If position V2 was not governed, it would be phonetically interpreted. The interpretation of an empty unsilenced $V$ varies across languages: it usually appears as some sort of a schwa (Neubarth and Rennison, 1998).

An empty $V$ position can also remain inaudible by virtue of being the last position in a phonological domain. The theory proposes the (parametrized) final empty nucleus (FEN) principle, which allows domain-final $\mathrm{V}$ positions to remain unexpressed as in kot 'an angle' (depicted in (7)).

${ }^{8}$ Orthographic symbols stand for an informal summary of the melodic elements attached to a particular skeletal position. 


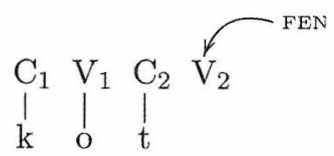

\section{Syllabic sonorants in government phonology and the analysis of the Slovene data}

We have pretheoretically proposed that (almost) any final sonorant sequence in the Celje dialect has a value of a syllable and that it is the second member of a sequence that functions as the most sonorous part of a syllable. In other words, the second member in a sequence becomes syllabic. Let us now see whether these observations are the expected outcomes in the given theoretical framework.

Despite a more or less unified idea about the building blocks of government phonology, the representation of syllabic consonants due to their vocalic and consonantal characteristics remains open to dispute.

One way to represent them is to propose that melodic material indicating the phonetic interpretation of a sonorant is attached to a V position (Toft, 2002; Harris, 1994). The shortcomings of this proposal are the following: (i) whether the phonetic realisation is that of a consonant or a vowel cannot be determined on the basis of melodic material itself; the type of the position elements attach to plays a decisive role, and (ii) alternations between syllabic and non-syllabic realisations of the same consonant in different forms of a word would imply resyllabification (switching of melodic material from one position to another), which is not recognized as a phonological process in government phonology.

Another proposal is that the same melodic material is attached to at least two adjacent positions (Scheer, 2004; Blaho, 2001). These positions are of different types, which implies the twofold character of a syllabic consonant. However, this proposal does not entirely overcome the shortcoming of the previous one concerning the interpretation of melodic material. For the purpose of this paper we need to make the following assumptions: (i) A CV pair represents a unit, therefore the interpretation of the melodic material shared within a unit is specific, in this case a segment with a vocalic function and consonantal phonetic realisation. (ii) Melodic material is shared by precisely two adjacent positions: a $\mathrm{C}$ and a following $\mathrm{V}$ position. ${ }^{9}$ (iii) In Slovene there are no syllabic consonants present lexically; whenever they appear they are the result of the application of phonology on a phonological string.

If a final empty $\mathrm{V}$ receives melodic material from the adjacent $\mathrm{C}$ position by means of spreading, we get a syllabic consonant, which is the case in the Celje dialect (depicted in (9)). This V position is thus phonetically realised and can therefore silence (by governing) the preceding $\mathrm{V}$ position. If there is no spreading into the last $\mathrm{V}$ position and consequently no sharing of the melodic material, the last empty $\mathrm{V}$ position is not phonetically realised and thus incapable of silencing the preceding $\mathrm{V}$ position. In this case a schwa is realised between the two sonorants (depicted in (8)).

\footnotetext{
${ }^{9}$ Other possibilities are discussed in Scheer (2004); Blaho (2001); Ferme (2004).
} 


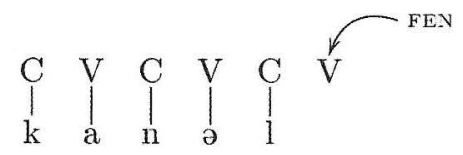

(9)

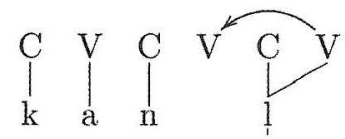

Let us take the alternation obrv/obrvi [obəru]/[obərvi] 'an eyebrow, nom. sg./gen.(=nom.)pl.' In contrast with the example above, phonetic realisations of the segment under inspection differ: $[\mathrm{u}]$ in the position of an expected syllabic consonant and $[\mathrm{v}]$ in the position where a non-syllabic consonant is expected. Toporišič (1978) argues that $[u]$ in the given example is the vocalised variant of the final sonorant. If 'vocalised' is translated to government phonology vocabulary as 'syllabic,' then Toporišič (1978) and our theory agree in explaining a phenomenon which at first glance seems very different from what we have observed in (9), but is in fact very similar depicted in (10) The structure (not taking into account the melodic material) of a syllabic / $\mathrm{v}$ / is the same as in the case of other syllabic consonants, the unexpected part is the phonetic interpretation. ${ }^{10}$ This is not surprising since glides are phonetically very close to vowels, therefore the distinction, if there is one, can be easily blurred. Further elaboration of this stipulation, however, is beyond the scope of this paper.

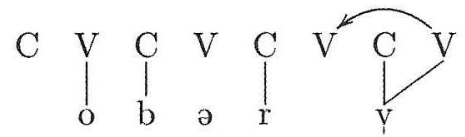

Let us recall that Toporišic $(1978)$ proposes the hardening of $/ \mathrm{j} /$ to $[\mathrm{i}]^{11}$ when it is a second member of a final sonorant sequence. In addition to this process another $/ \mathrm{j} /$ is added to the sequence due to the analogy with other cases. This way of dealing with sonorant sequencing with $/ \mathrm{j} /$ as a second member is radically different from previous observations made for other sonorant sequences. Let us see if a different analysis is really necessary.

10 Despite the difference in pronunciation, I claim that the melodic representation of a segment does not change (it is always the element $U$ ), the only difference being the type and number of relations that target the given position. A discussion on the real character of the alternation is beyond the scope of this paper and will be dealt with elsewhere.

11 It is interesting to note that Toporišič $(1978,46-47)$ actually uses two explanations concerning this phenomenon interchangeably. The first one is the one mentioned above, that is, the hardening of $/ \mathrm{j} /$ to $[\mathrm{i}]$ and adding another $/ \mathrm{j} /$, the second one is the insertion of the [i]. The two proposals provide the same surface output, however, there is a fundamental difference between them: the first one involves the alophonic explanation $(/ \mathrm{j} /$ turns into [i]) while the second one calls for the insertion of a new phoneme. 
We encounter two problems if we want to translate this proposal directly into our theory. The first one concerns the existence of a process that changes a consonant into a vowel, provided that each segment is represented by one position. The theory of government phonology does not recognize such a process. The second problem concerns the source of the element $\mathrm{I}$, which represents the additional $/ \mathrm{j} /$. We could stipulate that I first breaks the bond with its original position, attaches to the adjacent position and in the end spreads into its original position. Not only that this process is not recognized by the theory, it is also intuitively hardly plausable that an element that is frequently lost in weak positions (e.g. unaccented [i] is very often lost) would have enough strength to delink, link again and finally spread. In addition, from this point of view the phenomenon does not seem to be motivated by analogy in any way.

Having shown that Toporišič's proposal cannot be treated in our theory, let us go back to the previous analysis of final sonorant sequences and propose that sequences with $/ \mathrm{j} /$ behave exactly the same. We find that the surface result is very similar to the /v/ case: syllabic / $\mathrm{j}$ / is phonetically identical to the vowel /i/. The phonological structure of the word morij is depicted in (11).

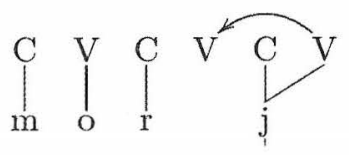

As for the additional $/ \mathrm{j} /$, the intuition of speakers shows that there is no such object. $^{12}$

To sum up, final sonorant sequences with $/ \mathrm{j} /$ as the second member are phonologically the same as other final sonorant sequences. In all cases alike the theory predicts that the second member becomes syllabic, i.e. that its melodic material spreads and attaches to the following $V$ position. "The hardening of $/ \mathrm{j} /$ into [i]," "the insertion of $/ \mathrm{i} /$ " or "adding a / $\mathrm{j} /$ due to analogy" turn out to be merely illusions fed by orthography.

\section{Conclusion}

In this paper I examined final sonorant sequences in the Celje dialect. After having provided the definition of a consonant cluster, I pointed out that given sequences cannot be treated as sonorant clusters, since they do not need to obey the sonority sequencing principle and always form a syllable on their own. These pretheoretical proposals were strongly supported by the analysis in the government phonology framework.

Furthermore, the analysis in the given theoretical framework dispensed with a belief in the idiosyncratic behaviour of sequences with $/ \mathrm{j} /$ as the second member, and showed that these sequences behave phonologically exactly the same as other final sonorant sequences.

12 An experiment shows that speakers cannot hear the difference between ladij 'a ship, gen.pl' and Ladi (a proper name). 


\section{References}

BLAHO, Sylvia (2001). The representation of Slovak syllabic consonants in strict CV. In The Odd Yearbook 6, 3-24. Department of English Linguistics, School of English and American Studies, Eötvös Loránd University (ELTE).

FERME, Alja (2004). Syllabic consonants in Slovene. Ms.

GOLDSMITH, John A. (1976). Autosegmental Phonology. Ph. D. thesis, MIT.

HARRIS, John (1994). English Sound Structure. Oxford: Blackwell Publishers.

KAYE, Jonathan D., Jean Lowenstamm, and Jean-Roger Vergnaud (1985). The internal structure of phonological elements: a theory of charm and government. Phonology Yearbook 2, 305-328.

KAYE, Jonathan D., Jean Lowenstamm, and Jean-Roger Vergnaud (1990). Constituent structure and government in phonology. Phonology 7, 193-231.

KENSTOWICZ, Michael (1995). Phonology in generative grammar. Oxford, Cambridge: Blackwell.

LOWENSTAMM, Jean (1996). CV as the only syllable type. In J. Durand and B. Laks (Ed.), Current Trends in Phonology: Models and Methods. Salford, Manchester: European Studies Research Institute (ESRI), University of Salford.

NEUBARTH, Friedrich and John R. Rennison (1998). An x-bar theory of Government Phonology. In S. Ploch (Ed.), Living on the Edge: 28 Papers in Honour of Jonathan Kaye, Volume 62 of Studies in Generative Grammar, 95-130. Mouton de Gruyter.

NEUBARTH, Friedrich and John R. Rennison (2005). Structure in Melody, and vice versa. Leiden Working Papers in Linguistics 2(4), 95-124.

SCHEER, Tobias (2004). A lateral theory of phonology. Vol 1: What is CVCV, and why should it be? Mouton de Gruyter, Berlin.

SREBOT Rejec, Tatjana (1992). Initial and final sonorant clusters in Slovene. Linguistica 32(2), 227-230.

TOFT, Zoë (2002). The Phonetics and Phonology of some Syllabic Consonants in Southern British English. ZAS Papers in Linguistics 28, 111-144.

TOPORIŠIČ, Jože (1959). Alternativni soglasniški sklopi slovenskega knjižnega jezika. JiS 4(7), 203-207.

TOPORIŠIČ, Jože (1978). Glasovna in naglasna podoba slovenskega jezika. Založba Obzorja.

UNUK, Drago (2003). Zlog v slovenskem jeziku. Ljubljana: Rokus: Slavistično društvo Slovenije (Slavistična knjižnica 7).

\section{Povzetek \\ ZVOČNIŠKA IZGLASJA V CELJSKEM GOVORU}

Članek obravnava izglasne zvočniške nize v celjskem govoru. Na podlagi definiranega termina izglasni soglasniški sklop ugotavljam, da celjski govor pravih izglasnih zvočniških sklopov ne pozna. Prav zato se v njem lahko uresničujejo skoraj vsi končni zvočniški nizi, pri čemer se drugi zvočniški člen skoraj brezizjemno ozloži.

Nazadnje so podrobneje preučeni primeri z izglasnim /j/, ki je edini izmed zvočnikov, pred katerega naj bi se vrival samoglasnik /i/. V okviru teoretičnega aparata vezalne fonologije pokažem, $\mathrm{da} \mathrm{v}$ tovrstnih primerih ne gre za izjemno obnašanje, temveč za popolnoma pravilen proces ozloženja drsnika /j/, katerega fonetična realizacija (ne pa tudi fonološka zgradba!) je enaka samoglasniku /i/. 